Центр воєнно-стратегічних досліджень Національного університету оборони України імені Івана Черняховського, Київ

\title{
Підходи до визначення раціональної послідовності автоматизації процесів управлінням технічним обслуговуванням та ремонтом воснної автомобільної техніки
}

\begin{abstract}
Резюме Визначено підходи щодо раціональної послідовності автоматизації процесів технічного обслуговування та ремонту воєнної автомобільної техніки.

Ключові слова: автоматизований процес; апаратно-програмний комплекс.
\end{abstract}

Постановка проблеми. У сучасних умовах експлуатації воєнної автомобільної техніки у технічних підрозділах військових частин виникають складності щодо визначення виробничої спроможності ремонтних органів цих частин 3 технічного обслуговування (ТО) та ремонту воєнної автомобільної техніки. Відповідно, виникають ускладнення під час прийняття планових рішень щодо технічного обслуговування, а саме: визначення кількості постів щоденного технічного обслуговування (ЩТО), номерного технічного обслуговування (ТO-1, ТО-2) та поточного ремонту (ПР) [2]. Водночас у технічних частинах військових частин відсутні суворі нормативи із трудомісткості та тривалості технічного впливу завдяки відсутності такої інформації щодо сучасної імпортної техніки, особливо термінів iï експлуатації. Отже виникають складнощі щодо визначення виробничої спроможності ремонтних органів військових частин 3 технічного обслуговування (ТО) та ремонту (Р) воєнної автомобільної техніки. Упровадження автоматизованих систем має внести свої корективи до нормативів 3 технічного обслуговування та ремонту, до того ж зменшуючи трудомісткість.

Аналіз останніх досліджень i публікацій. Роботи [6, 7], присвячені впровадженню інформаційних систем для прийняття рішення в галузі експлуатації рухомого складу автопоїздів, 3 метою мінімізації енергетичних витрат на виконання транспортних перевезень [5]. Наприклад, у [6] йдеться про визначення питомих енерговитрат рухомого складу автопоїздів, де за вихідні дані взято технічні характеристики рухомого складу. У [7] окреслені визначення питомих енерговитрат стосовно вивезення вантажів 3 урахуванням техніко-експлуатаційних показників автомобілів 3 урахуванням умов експлуатації. Розроблена програма розрахунку питомих енерговитрат на здійснення автоперевезень дає змогу автоматизувати процес прийняття рішення - вибір рухомого складу, який найбільш приємний для вирішення службових завдань. Однак у визначених i деяких інших публікаціях підходи до визначення раціональної послідовності автоматизації процесів управлінням технічним обслуговуванням та ремонтом воєнної автомобільної техніки не досліджені.

Метою статті $\epsilon$ пошук прийнятних підходів щодо автоматизації процесів управління технічним обслуговуванням та ремонтом воєнної автомобільної техніки, 3 подальшим впровадженням.

Викладення основного матеріалу. Автоматизація технологічного процесу, в частині обробки інформації та вироблення рішення, передбачає часткове або повне його здійснення інформаційними системами, що діють за визначеними алгоритмами. На базі інформаційних систем розробляються апаратно-програмні комплекси, до складу яких входять різні технічні прилади, що реалізують обробку даних $\mathrm{i}$ сприяють виробленню рішення. Для споживача інформації дуже важливою характеристикою $є$ ii адекватність, тому створенням інформаційних систем та апаратнопрограмних комплексів займається експертна група, яка визначає алгоритми обробки даних та методики напрацювання рішень для інформаційної системи.

Апаратно-програмний комплекс, який розроблений у цивільній сфері [4], реалізовує спосіб керування ремонтними діями, звертаючи увагу, насамперед, на вузли та агрегати автотранспортної техніки завдяки ідентифікації об'єкта, який підлягає ремонту, a саме: діагностику об'єкта; керування ремонтними процесами; накопичення, зберігання та наочне уявлення відомостей про 
об'єкт, облік виявлених дефектів. Під час ідентифікації в об'єкті виділяють базові складальні одиниці. Діагностують об'єкт шляхом виміру параметрів базових складальних одиниць. Залежно від результатів вимірів до ремонтних впливів враховують ремонт або заміну базової складальної одиниці 3 деталями, що входять до іiі складу. Деталі та складальні одиниці 3 коефіцієнтом змінності, що вище заданого порогового значення, замінюють без проведення діагностики. Скорочуються тимчасові матеріальні витрати під час проведення ремонту [1].

Підтримання воєнної автомобільної техніки у технічно-справному стані значною мірою залежить від рівня розвитку та умов функціонування виробничо-технічної бази парків автомобільної техніки військових частин [8-10]. У сучасних умовах розвиток виробничо-технічної бази військових частин відстає від темпів розвитку парку сучасної воєнної автомобільної техніки. У багатьох військових частинах збільшується доля парку сучасної техніки 3 високими ресурсними пробігами.

\section{Апаратно-програмний}

(автоматизований) комплекс, якщо його застосовувати для сучасної воєнної автомобільної техніки дає змогу накопичувати історію ремонтних робіт за видами техніки (групами експлуатаціiі) i може автоматично розраховувати прогноз відмов техніки у військах, іiі складальних вузлів, агрегатів та деталей. Також комплекс дає змогу накопичувати як історію отримання запчастин, так i історію закупівель, може розраховувати витрати на придбання необхідних запасних частин i матеріалів, відповідно він може автоматично надавати оператору системи інформацію щодо можливих варіантів закупівель. Комплекс також містить у собі блок довідкової інформації щодо технологічних процесів ремонту та блок виробничих завдань на виконання ремонтно-відновлювальних робіт, тим самим оператор системи може надавати точні виробничі завдання, точно розраховувати розміри оплати праці ремонтників (за потребою) [1]. Для підвищення ефективності праці під час проведення технічного обслуговування та ремонту пропонуються різні системи 3 автоматизації зазначених процесів. Окремі види робіт 3 технічного обслуговування та ремонту сучасної воєнної автомобільної техніки мають можливість щодо приведення ïx до повної або часткової автоматизації із зменшенням частки залучення людини до цих виробничих процесів. Основний ефект від застосування систем автоматизації досягається завдяки зменшенню часу на вирішення як окремих задач, так і головної мети технічного обслуговування та ремонту забезпечення бойової готовності техніки завдяки мінімальних витрат трудових i матеріальних ресурсів із зменшенням шкідливих наслідків для оточуючого середовища від експлуатації воєнної автомобільної техніки.

Ось чому для автопарків військових частин i пропонується застосувати досвід цивільних автопідприємств щодо поширеного способу технічного обслуговування та ремонту за допомогою автоматизованої системи управління процесами та ресурсами.

Згідно 3 цим способом на кожній складній частині, на технологічному оснащенні та інструментах 3 попередньо введеними в них ідентифікаційними даними розміщуються радіочастотні ідентифікатори та зчитувачі ідентифікаційних даних із радіочастотних ідентифікаторів, яких підключено до комп'ютерів. До того ж у пам'ять центрального комп'ютера введена попередньо підготовлена цифрова відеоінформація, яка містить в собі поопераційні відеокадри, які відображують відповідні складові частини складних технічних систем (СТС) у послідовності виконання технологічних операцій та інструменти. Перед початком робіт 3 технічного обслуговування та ремонту СТС цифрову інформацію під керуванням центрального комп'ютера пересилають 3 пам'яті центрального комп'ютера у пам'ять комп'ютерів відповідних автоматизованих робочих місць (АРМ) і виносного терміналу, на екранах моніторів яких здійснюють візуалізацію технологічних операцій, що виконуються для технічного обслуговування та ремонту СТС [3]. Проте треба зазначити, що радіочастотні ідентифікатори $€$ недостатньо надійними, бо схильні до дії агресивного середовища.

До апаратно-програмного комплексу (рис. 1) поступає інформація від об'єктів, які обслуговуються або ремонтуються шляхом діагностики об’єктів кожної видової групи із використанням вимірювального обладнання, яке підключається до локального серверу. Сам сервер керує процесом виміру параметрів попередньо ідентифікованого об'єкта. Це забезпечує можливість електронної обробки 
результатів діагностики на двох рівнях: у локальному сервері видової групи i в центральній електронно-обчислювальній машині, до якої поступає інформація від локальних серверів всіх видових груп. Можливість незалежних оцінок результатів діагностики, а саме і якість ремонтних робіт, забезпечується завдяки локальному серверу кожної групи об'єктів та оснащення електронно-обчислювальних машин автономними базами даних.

Система контролю якості технічного обслуговування та ремонту складається 3 центру управління технічним обслуговуванням і ремонтом (ЦУТОР), до складу якого входять: комплексний серверний пристрій 1,_диспетчерська робоча станція 2 та

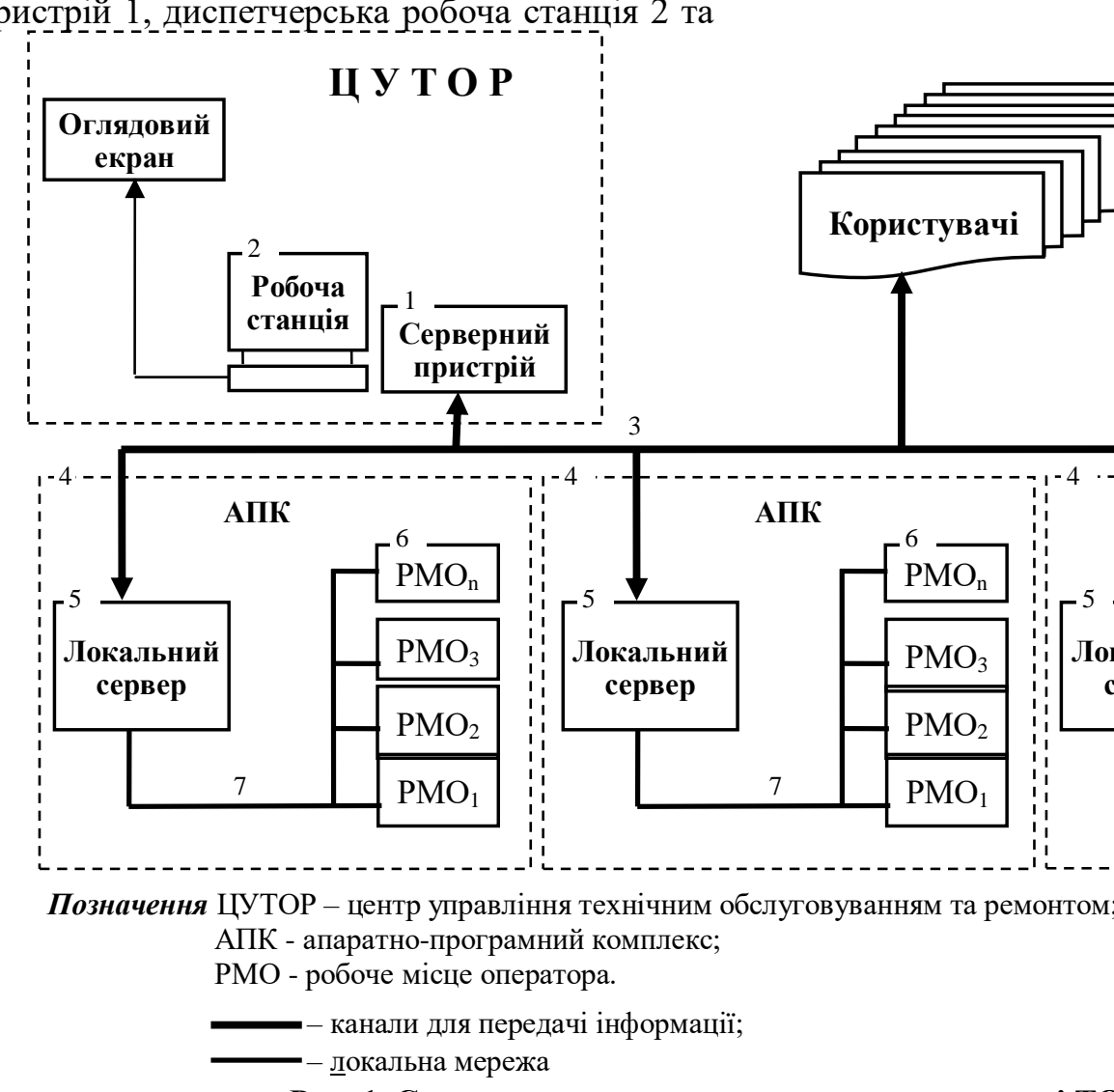

мережеві комунікаційні пристрої, які організовують канали 3 двостороннього інформаційного зв'язку завдяки апаратнопрограмним комплексам 4, кожен 3 яких призначений для діагностики об'єктів визначеного виду і включає: локальний сервер 5, вимірювальне обладнання, яке скомпоноване у робочі пости 6, котрі, відповідно, з'єднані із вказаним раніше сервером 5 локальною магістраллю 7 для обміну даними. ЦУТОР створено на платформі стандартного обладнання, яке використовується для подібних проєктів i засобів вимірювальної техніки, які оснащені спеціалізованим програмним забезпеченням [4].

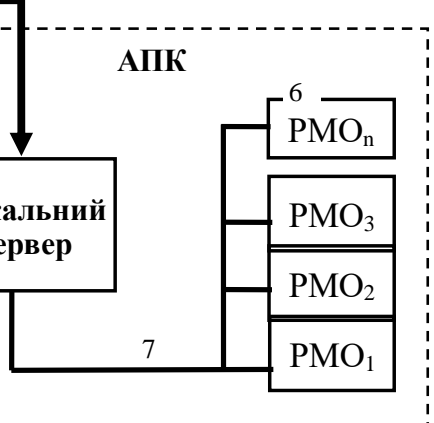

Рис. 1. Структурна схема системи контролю якості ТО та ремонту

Автоматизацію технологічного процесу реалізує алгоритм прийняття рішення на базі обробки вихідних даних щодо об'єкта та навколишнього середовища. Прикладом автоматизації прийняття рішення є роботи в галузі експлуатації рухомого складу вантажних автомобілів, де описано алгоритм вибору автопоїздів для перевезення габаритних вантажів 3 метою мінімізації енергетичних витрат на виконання транспортних перевезень [5]. За вихідні дані взято технічні характеристики рухомого складу та умови експлуатації. Розроблена програма розрахунку питомих енерговитрат на здійснення автоперевезень дає змогу автоматизувати процес прийняття рішення вибір рухомого складу сучасної воєнної автомобільної техніки, який найбільш приємний для вирішення службових завдань сьогодення [6, 7].

Висновки.

Адаптація наданої інформації до особливостей функціонування військового відомства дасть змогу підвищити оперативність виконання робіт 3 технічного обслуговування та ремонту, а також зменшити фінансові витрати на організацію діяльності виробничо-технічної бази ремонтного 
підрозділу військової частини для виконання різних за обсягом видів ремонтних робіт.

у подальших дослідженнях $\epsilon$ необхідність дослідити підходи до визначення оптимальної послідовності автоматизації процесів управлінням технічним обслуговуванням та ремонтом воєнної автомобільної техніки, яка знаходиться на зберіганні.

\section{СПИСОК ВИКОРИСТАНОЇ ЛІТЕРАТУРИ}

1. Терентьев А. В. Совершенствование методики расчета производственной программы ТО и ТР подвижного состава : дис. ... канд. техн. наук. Санкт-Петербург, 2009. 152 с.

2. Опанасюк Д. Б., Можаровський О. Є.,

Бегерський М. М., Опанасюк Є. Г. автопоїзда методом фізичного моделювання. Вісник Житомирського державного технологічного університету. Житомир, 2019. № 1 (83). С. 25-34.

3. Антонов Д. А. Теория устойчивости движения многоосных автомобилей. Москва : Машиностроение, 1978. 216 с.

4. Нагорний С. В., Шраменко Н. Ю. Аналіз функціонування логістичних систем при доставці вантажів. Міжвузівський збірник "Наукові нотатки”. Луцьк, 2010. № 28. С. 353-357.
5. Чабанний В. Я., Осипов І. М. Тенденції розвитку виробничо-технічної бази автомобільного транспорту. Збірник наукових праць ЦНТУ. Техніка в сільськогосподарському виробництві, галузеве машинобудування, автоматизачія. Кропивницький, 2011. № 24 (39), Ч. 2. С. 23-26.

6. Виробничо-технічна база підприємства автомобільного транспорту : навч. посіб. / В. В. Біліченко та ін. Вінниця : ВНТУ, 2013.

7. Удосконалення моделі технічного обслуговування i ремонту автобронетанкової техніки силових структур для забезпечення іiі експлуатаційної надійності на періоді підвищеної інтенсивності відмов : труди 12 наук-практ. конф., м. Харків, 13 - 14 квіт. 2016 р. Харків, 2016. С. 285-286.

8. Терминология системы ремонта автомобильной техники : справочник / А. Г. Шмаков и др. Челябинск, 2005. 68 с.

9. Способ управления ремонтными воздействиями на узлы и агрегаты автотракторной техники : декларац. пат. 2582519 Россия: МПК G01M17/00; заявл. 01.04.14; опубл. 27.04.16, 8 с.

10. Способ ремонта и технического обслуживания и применяемые в способе аппаратнопрограммный комплекс для диагностики и система для контроля качества ремонта и технического обслуживания : декларац. пат. 2357215 Россия: МПК G01D21/00, заявл. 10.08.08; опубл. 27.05.09, 23 с

Стаття надійшла до редакційної колегії 20.08.2020

\section{Approaches to determining of the rational sequence of automation of control processes for maintenance and repair military vehicles}

\section{Annotation}

In modern conditions of operation of military vehicles in the technical units of military units there are difficulties in determining the ability of the repair bodies of these units for maintenance and repair of military vehicles. Accordingly, there are difficulties in making planned maintenance decisions, namely: determining the number of daily maintenance posts, numbered maintenance and maintenance.

The aim of the article is to find approaches to automate the processes of management of maintenance and repair of military vehicles, with further implementation.

Hardware-software (automated) complex in case of its application allows to collect statistics of repair works by types of equipment (groups of operation) and to automatically calculate forecasts of failures of equipment in armies, its assembly units, units and details. The complex also allows you to accumulate as a history of procurement and receiving of the necessary spare parts, calculating it's and automatically provide with the necessary information on possible procurement options to the system operator.

The automation of the technological process is realized by the decision-making algorithm based on the processing of the initial data concerning the object and the environment. An example of decision-making automation are works in the field of operation of rolling stock of trucks, where the algorithm for selecting road trains for the transport of bulky goods in order to minimize energy costs for transportation is described.

Adaptation of the provided information to the peculiarities of the functioning of the military department will increase the efficiency of maintenance and repair work, as well as reduce the financial costs of organizing the production and technical base of the repair unit of the military unit to perform various types of repairs.

Keywords: automated process; hardware and software complex. 